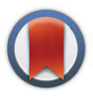

CrossMark

\& click for updates

Cite this: Org. Chem. Front., 2015, 2, 300

DOI: $10.1039 / \mathrm{c} 5 \mathrm{q} 090005 \mathrm{k}$

rsc.li/frontiers-organic

\section{Correction: Enyne [4 + 4] photocycloaddition with polycyclic aromatics}

\author{
Buddha B. Khatri, Svitlana Kulyk and Scott McN. Sieburth*
}

Correction for 'Enyne [4 + 4] photocycloaddition with polycyclic aromatics' by Buddha B. Khatri et al., Org. Chem. Front., 2014, 1, 961-964.

We note that Scheme 4 of this paper has an incorrect structure for compound 17. Below is the full Scheme 4 with the correct structure.<smiles>c1ccc2cc3ccccc3cc2c1</smiles>

14<smiles>Cn1cccc(COCc2c3ccccc3cc3ccccc23)c1=O</smiles>

16
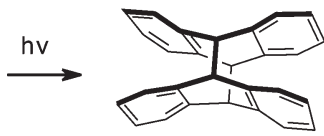

15

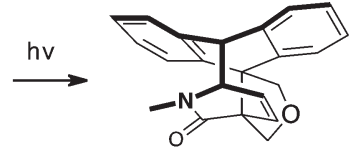

17

The Royal Society of Chemistry apologises for these errors and any consequent inconvenience to authors and readers. 